Boston University School of Law

Scholarly Commons at Boston University School of Law

Faculty Scholarship

$1-7-2014$

\title{
Classical Liberal Constitution or Classical Liberal Construction?
}

Gary S. Lawson

Boston University School of Law

Follow this and additional works at: https://scholarship.law.bu.edu/faculty_scholarship

Part of the Constitutional Law Commons

\section{Recommended Citation}

Gary S. Lawson, Classical Liberal Constitution or Classical Liberal Construction? , in No. 14-2 Boston University School of Law, Law and Economics Research Paper (2014).

Available at: https://scholarship.law.bu.edu/faculty_scholarship/124

This Book Review is brought to you for free and open access by Scholarly Commons at Boston University School of Law. It has been accepted for inclusion in Faculty Scholarship by an authorized administrator of Scholarly Commons at Boston University School of Law. For more information, please contact lawlessa@bu.edu. 


\section{BU School of Law}

\section{Classical liberal Constitution or Classical liberal CONSTRUCTION?}

Boston University School of Law Working Paper No. 14-2

(January 7, 2014)

Gary Lawson

This paper can be downloaded without charge at:

http://www.bu.edu/law/faculty/scholarship/workingpapers/2014.html 


\title{
Classical Liberal Constitution or Classical Liberal Construction?
}

\author{
Gary Lawson* \\ (forthcoming N.Y.U. J. L. \& LIBERTY)
}

\begin{abstract}
In The Classical Liberal Constitution: The Uncertain Quest for Limited Government (2013), Richard Epstein says that he "incorporates but goes beyond" originalist theory by calling for adjudication "in sync with" classical liberal theory political theory, which Professor Epstein claims underlies the Constitution. Without in any way detracting from the numerous virtues of this book, I argue that this is primarily a work of constitutional construction rather than constitutional interpretation. From the standpoint of interpretation, the background rules that best supplement the constitutional text are found in eighteenth-century fiduciary law rather than in classical liberal political theory, though the latter is relevant in many contexts. From the standpoint of adjudication, the Constitution implicitly prescribes a set of default rules, rather than reliance on political theory, to govern in the face of interpretative indeterminacy. Hence, Professor Epstein's adjudicative scheme cannot be derived from interpretation of the Constitution but must result from constitutional construction.
\end{abstract}

It is a great honor to be invited to comment on Richard Epstein's magnificent new book The Classical Liberal Constitution: The Uncertain Quest for Limited Government. ${ }^{1}$ Its remarkable scope, depth, and profundity handily place it among the leading works in the everburgeoning field of constitutional theory. The fact that no one will be surprised by this

\footnotetext{
* Philip S. Beck Professor, Boston University School of Law. This Comment was prepared in connection with a conference on February 10, 2014 at New York University School of Law. I am grateful to the N.Y.U. Journal of Law and Liberty and the Classical Liberal Institute for inviting me and to Professor Richard Epstein for providing me with more than 30 years of inspiration.

1 Richard A. Epstein, The Classical Liberal CONSTitution: THe UnCERTAin Quest FOR Limited GOVERNMENT (2014).
} 
achievement $^{2}$ should make us work harder not to diminish it; Richard Epstein is a national treasure who is dangerously easy to take for granted.

Characteristically, the book sweeps broadly, addressing issues from standing to executive power to due process to freedom of religion. It aims to be a comprehensive account of American constitutionalism. In a work so panoramic, in which the focus is on explaining the political theory underlying the Constitution (and the countervailing political theory underlying the Constitution's effective demise as an operational document), even almost 600 pages of text leave relatively little room to deal with matters of interpretative theory. Yet in barely more than a dozen pages, ${ }^{3}$ Professor Epstein manages to lay out a rigorous theory of constitutional interpretation, and it is on that aspect of the book that I will focus my attention. That narrow focus should not obscure the importance of the remaining 567 pages of the work, all of which merit careful attention and profound respect and any portion of which would justify a lengthy comment.

Professor Epstein contests - or at the very least says that he "incorporates but goes beyond" 4 - two of the leading contemporary theories of constitutional interpretation: originalism and living constitutionalism. ${ }^{5}$ Obviously, neither he nor I think this choice exhausts the range of preferred constitutional methodologies. In particular, pragmatism, ${ }^{6}$ eclecticism, ${ }^{7}$ perfectionism, ${ }^{8}$

\footnotetext{
2 I was recently part of a conversation involving identification of the five smartest people with whom one has ever been in a room. Richard Epstein's name figured prominently in that conversation.

3 See id. at 45-56, 68-71. See also id. at 570-83 (reinforcing many of the themes in the foregoing pages).

4 Id. at 45 .

5 See id.

6 See, e.g., Daniel A. Farber, Legal Pragmatism and the Constitution, 72 MINN. L. REV. 1331 (1988); RICHARD A. POSNER, OVERCOMING LAW (1996).

7 See, e.g., Michael C. Dorf, Integrating Normative and Descriptive Constitutional Theory: The Case of Original Meaning, 85 GEO. L.J. 1765, 1787-96 (1997).
} 
and common law constitutionalism ${ }^{9}$ quickly leap to mind as prominent alternatives. But time and space are scarce resources, and one must choose one's targets. Because I defend a species of originalism, the merits vel non of living constitutionalism or any methodologies not addressed by Professor Epstein are not pertinent to this Comment. I am fairly confident that Professor Epstein and I would largely agree on the inadequacy, though not necessarily on all of the reasons for the inadequacy, of all of these other modes of interpretation. Instead, the relatively modest, but nonetheless important, disagreement with Professor Epstein on which I want to focus concerns whether originalism can carry all of the necessary interpretative water without a supplementing framework drawn from classical liberal political theory. With one very important qualification, described at the conclusion of this Comment, I think that it can.

Part I of this Comment describes Professor Epstein's interpretative theory, sets forth the difference between theories of interpretation and theories of adjudication (sometimes framed as the difference between constitutional interpretation and constitutional construction), and explores the extent to which Professor Epstein is presenting one or the other kind of theory. Part II analyzes the interpretative component of Professor Epstein's project, concluding that he is right that originalist interpretation requires background rules to be effective as an interpretative theory but doubting that classical liberalism, rather than eighteenth-century fiduciary law, is the primary source of those background rules. Part III examines Professor Epstein's adjudicative theory, which calls for constitutional adjudication "in sync with" 10 classical liberal political principles, suggesting that, while this approach may be normatively attractive as a constitutional

8 See, e.g., James E. Fleming, Securing Constitutional Democracy: The Case of Autonomy (2006).

9 See, e.g., David A. Strauss, The Living Constitution (2010).

10 EPSTEIN, supra note 1, at 53-54. 
construction, the Constitution itself implicitly prescribes a very different set of adjudicative principles.

"What rules and techniques of interpretation are necessary and proper to grasp the meaning of any constitutional text?"11 Professor Epstein breaks this "disarmingly simple question"12 into two parts. The first part seeks the correct interpretative answer as a matter of first principles. ${ }^{13}$ The second asks how previous interpretative efforts - and specifically previous interpretations that are erroneous as a matter of first principles - should affect present interpretations. $^{14}$

With respect to first principles, Professor Epstein takes the original public meaning of the constitutional text as the starting point for interpretation, ${ }^{15}$ thereby rejecting - as do most (though not quite all) modern originalists - reliance on the subjective intentions of the original constitutional drafters, whoever that term may be understood to encompass. ${ }^{16}$ But he maintains

\footnotetext{
11 Id. at 45.

$12 I d$.

13 See id.

14 See id. Obviously, a key premise of this breakdown is that previous interpretations are not determinative of meaning as a matter of first principles. Advocates of some species of "common law constitutionalism" might be tempted to dispute this premise, but those advocates are typically setting forth theories of adjudication or governance rather than theories of meaning.

15 See id. at 46.

16 A significant block of originalist scholars continues to focus, at least to some degree, on historically concrete intentions. See, e.g., Larry Alexander, Simple-Minded Originalism, in THE CHALLENGE OF ORIGINALISM: ESSAYS IN COnstitutional THEORY 87 (Grant Huscroft \& Bradley W. Miller eds., 2011); Richard S. Kay, Adhering to the Original Intentions in Constitutional Adjudication: Three Objections and Responses, 82 Nw. U.L. REV. 226 (1988); Robert G. Natelson, The Founders' Hermeneutic: The Real Original Understanding of Original Intent, 68 OHIO ST. L.J. 1239 (2007).
} 
that this starting point requires many important extensions and elaborations in order to provide an adequate account of constitutional meaning. Among the most prominent of Professor Epstein's elaborating propositions are:

(1) Some constitutional provisions contain technical words of art that require background knowledge to understand. ${ }^{17}$

(2) Other provisions involve "grand abstractions" that can be grasped only through "explicit resort to the dominant political theory" that underlies the document. ${ }^{18}$

(3) Constitutional provisions cannot be viewed in isolation from the structural whole. ${ }^{19}$

(4) Once one has identified the apparent original public meaning, one must ask "whether the text as written is subject to a set of unspoken qualifications that either supplement or restrict its application." 20

(5) Those unspoken qualifications most notably include an anti-circumvention principle to prevent governmental actors from "skirting a constitutional norm without violating its literal meaning,"21 a set of police powers that provide justifications for governmental actions that appear to violate unqualified textual provisions, ${ }^{22}$ and the judicial provision of remedies for constitutional violations. ${ }^{23}$

\footnotetext{
17 EPSTEIN, supra note 1, at 46.

$18 I d$.

19 Id. at $46-47$.

$20 \quad$ Id. at 47.

21 Id. at 48-49.

22 Id. at 49.

23 Id. at 50.
} 
(6) Interpretation undertaken pursuant to these unspoken qualifications frequently "leads to a constant balancing of interests to take into account the justifications that might be offered for an admitted restriction on a constitutional right."24

(7) This interpretative enterprise, including the dialectical movement from anticircumvention norms to police power justifications to remedies and back again, must be conducted "in light of supplemental norms that arise from within th[e] classical liberal tradition," ${ }^{25}$ because "[i]n its enduring provisions, our Constitution is most emphatically a classical liberal document."26

Once the correct answer as a matter of principle has been determined by the foregoing method, Professor Epstein allows certain past errors to take precedence over that meaning. The determination of which errors have that kind of prescriptive (in the property law sense of the term) effect "does not admit any standard interpretive answer.",27 Rather, "powerful value judgments have to work themselves into the system, to ask whether the rejection of wellestablished doctrine will advance or harm the position of the nation as a whole."28

This is a remarkably rich interpretative theory to be set forth in such a short space, and nothing that I say here should detract from the sheer awe with which I regard Professor Epstein's ability to pack enormous ideas into a manageable package. But I was invited to this conference to comment on (read: criticize) Professor Epstein's constitutional methodology, so here we go.

\footnotetext{
24 Id. at 54.

25 Id. at 53.

26 Id.

27 Id. at 70 .

${ }^{28}$ Id.
} 
Focusing on the task of discerning meaning from the standpoint of first principles, propositions (1) and (3) would be accepted by everyone. The remaining propositions lay out a more controversial method that places heavy reliance on political theory. The big question is: a controversial method for doing what? The seemingly obvious answer is: "for interpreting the Constitution." But, on reflection, it is not at all clear that this seemingly obvious answer is correct. It is not at all clear, in other words, that this book is really meant to be about constitutional interpretation.

It is now standard in the literature on constitutional theory to distinguish constitutional interpretation from constitutional construction. ${ }^{29}$ The former "is the activity that discerns the communicative content (linguistic meaning) of the constitutional text."30 The latter is defined by one leading theorist as "the activity that determines the content of constitutional doctrine and the legal effect of the constitutional text,"31 by another leading theorist as "implementing and applying the Constitution using all of the various modalities of interpretation,",32 and by yet another as "the activity of applying ... meaning to particular factual circumstances." 33 I would use slightly different terminology to distinguish between the activities of constitutional

29 The interpretation/construction distinction is widely attributed to Keith Whittington, see KEITH E. WHITTINGTON, Constitutional Construction: Divided Powers And Constitutional MeAning 1-2 (1999), though the distinction between ascertaining the meaning of a text and deciding how to apply the text in action is ancient.

30 Lawrence B. Solum, Originalism and Constitutional Construction, 82 FORDHAM L. REV. 453, 457 (2013). It is not at all clear that communicative content and linguistic meaning are precisely the same thing if one considers certain pragmatic features of communication to be outside the boundaries of "linguistic meaning." See id. at 464-65. I use the term "meaning" to describe communicative content, including its pragmatic elements.

31 Id.

32 JACK M. BALKIN, LIVING ORIGINALISM 4 (2011).

33 Randy E. Barnett, Interpretation and Construction, 34 HARV. J.L. \& PUB. POL'Y 65, 66 (2011). 
interpretation and constitutional adjudication. ${ }^{34}$ That is, interpretation is the ascertainment of the communicative signals contained in a text, while construction is the production of norms for real-world decision-making - i.e., adjudication -- undertaken pursuant to (or in the name of) the text. The two activities need not be related to each other at all, and if they are related, that relationship is contingent. The activity of interpretation is a positive rather than normative activity: one is seeking to determine objective facts about the communicative signals conveyed by a text. ${ }^{35}$ The activity of adjudication or construction is normative: one is seeking to determine the proper course of action in a real-world setting. ${ }^{36}$ The two are related only if one determines, as a normative matter, that the proper course of action in any particular circumstance is to act in accordance with the communicative signals contained in the interpreted text. And that is a

34 See Gary Lawson, On Reading Recipes . . and Constitutions, 85 GEO. L.J. 1823, 1823 (1997). I have developed this distinction at greater length elsewhere. See Gary Lawson, No History, No Certainty, No Legitimacy . . . No Problem: Originalism and the Limits of Legal Theory, 64 FLA. L. REV. 1551, 1555-56 (2012); Gary Lawson, Originalism without Obligation, 93 B.U.L. REV. 1309, 1312-15 (2013). Mitch Berman and Kevin Toh have recently urged that nestled in between theories of interpretation and theories of adjudication stand theories of law, and that distinguishing theories of law from theories of adjudication better isolates the key issues in constitutional (or at least originalist constitutional) theory. See Mitchell N. Berman \& Kevin Toh, On What Distinguishes New Originalism from Old: A Jurisprudential Take, 82 FORDHAM L. REV. 545 (2013). I suspect they are right to maintain that many originalists are implicitly - and sometimes explicitly -- articulating theories of law, see, e.g, Randy E. Barnett, The Gravitational Force of Originalism, 82 FordHAM L. REV. 411, 417-18 (2013); Steven G. Calabresi \& Saikrishna B. Prakash, The President's Power to Execute the Laws, 104 YALE L.J. 541, 552 (1994), and to the extent that Professors Berman and Toh are trying to describe the landscape of modern originalist theory, there appears to be much to their position. For myself (and Professors Berman and Toh are right to characterize my position as "idiosyncratic," Berman \& Toh, supra, at 548 n.16), I am not prepared to say categorically that originalism is a way to determine the law, because I incline towards a natural-law metaphysics. Cf. Mark Greenberg, Legislation As Communication? Legal Interpretation and the Study of Linguistic Communication, in PHILOSOPHICAL FOUNDATIONS OF LANGUAGE IN THE LAW 217 (Andrei Marmor \& Scott Soames eds., 2011) (distinguishing the communicative content of a statute from its contribution to the content of law). A properly formulated natural law theory could look in practice much like a positivist theory in which the original meaning of the Constitution might play a role -- but that is a topic for another day.

35 See Barnett, supra note 34 , at 415.

36 Just to be clear: I do not adhere to a hard Humean distinction between facts and values. Quite to the contrary, I believe that there are proper norms of human conduct that are grounded in actual facts about people and the world in which they live. See, e.g., TARA Smith, Viable VAlues: A Study OF LifE AS The RoOT AND REWARD OF

MORALITY (2000). But those facts are of a different kind than facts about the meaning of a text. The techniques for discerning communicative signals in the Constitution will not necessarily yield good information about proper moral conduct, no more than they will necessarily yield good information about quantum mechanics or how to make an omelet. 
determination that can only be made through moral theory; interpretative theory is not suited for addressing that kind of question, no more than is astronomy, philology, or forensic science.

Nothing in originalism as a theory of ascertaining meaning entails, or even suggests, that real-world decisions should be made in accordance with that ascertained meaning, and nothing in originalism as a theory of adjudication entails, or even suggests, that originalism is correct as an interpretative theory. In the latter case, for example, one could perfectly well think that originalism is the right way to decide real-world cases even if one believes that originalism is the wrong way to discern communicative signals, perhaps because one thinks that originalism yields results that are normatively superior to those derived from a more "correct" interpretative method, better fits some sense of the institutional role of various actors, or yields adequate answers at a more reasonable cost than other methods that might in theory be more reliable. Similarly, one could believe that originalism is the best (or even, as do I, the uniquely correct) method for ascertaining the Constitution's communicative signals but reject it as a tool for decisionmaking, for any or all of the kinds of reasons given above. One could certainly conclude that originalism is the correct tool for both interpretation and adjudication, but those conclusions are logically independent and must be validated by very different chains of reasoning. ${ }^{37}$

Thus, the preliminary question for this Comment is whether Professor Epstein is trying to ascertain the communicative signals in the Constitution or trying to prescribe a course of conduct for governmental actors. Obviously, he is doing both to some extent. Professor Epstein's discussion of precedent, for example, is entirely geared towards adjudication rather than interpretation, as it describes circumstances in which real-world adjudication should turn on something other than ascertained constitutional meaning. He is not claiming, as some common-

37 See Keith E. Whittington, Originalism: A Critical Introduction, 82 FORDHAM L. REV. 375, 400 (2013). 
law constitutionalists might claim, that precedents serve as sources of meaning as a matter of first principles. His primary discussion of first-principle determination of meaning is more ambiguous about its goals. Propositions (1)-(3) above all seem aimed at identifying the factual meaning of the document. Propositions (4)-(7), on the other hand, all seem aimed primarily at prescribing rules for adjudicative actors, though they could also be seen as attempts to flesh out communicative meaning. At some points, Professor Epstein writes as though his entire framework is aimed at identifying the appropriate background rules for discerning the Constitution's communicative content. ${ }^{38}$ At other times, however, the elaborating propositions are justified as necessary "to ensure that constitutional interpretation produces workable and sensible results in light of the overall design and purpose of the contested provision," ${ }^{39}$ which is a normative argument that sounds in adjudicative rather than interpretative theory.

This academic gobbledy-gook is important because if Professor Epstein is making a normative case for a particular kind of adjudicative theory, then I have nothing useful to say about it. One can only usefully comment on normative arguments in normative terms, and for more than a quarter century, I have striven very hard to avoid congesting the law reviews with normative observations that are not validated by foundationally sound arguments. ${ }^{40}$ As it happens, I am largely sympathetic to Professor Epstein's normative position, but there is no particular reason why anyone should find that fact intellectually interesting.

Accordingly, I am going to proceed for the moment - perhaps incorrectly -- as though Professor Epstein intends his interpretative methodology to be the appropriate tool for discerning

38 See EPSTEIN, supra note 1, at 50-51.

39 Id. at 47.

40 For a brief personal history on this point, see Gary Lawson, Truth, Justice, and the Libertarian Way(s), B.U.L. REV. 1347, 1347-48 (2011). To be clear: I do not sit in judgment of others who feel freer to share normative views that are not foundationally grounded. I am simply not intellectually comfortable doing it. 
constitutional meaning. Of course, as was already noted, much of Professor Epstein's project is explicitly about adjudication rather than interpretation. As it happens, the Constitution purports - albeit indirectly -- to give directions to adjudicative actors, and so after discussing interpretative theory, I will subsequently, in Part III, describe (without prescribing) the methods of adjudication indicated by the Constitution's original meaning and show how those methods differ from Professor Epstein's adjudicative model. Because Professor Epstein's adjudicative model cannot be derived from the Constitution itself, it operates as a construction rather than an interpretation of the Constitution. It is a simply splendid construction that I hope gets widely adopted by real-world actors, but it is a construction nonetheless. For the moment, however, let us turn to the ascertainment of constitutional meaning.

\section{II}

Professor Epstein is absolutely right that naked textualism is an ineffective method for discerning the Constitution's communicative signals. ${ }^{41}$ All communication takes place in a context, and without knowing the context, the communication cannot be understood. Precisely the same words, even within a single language, ${ }^{42}$ can have very different meanings if they are embedded in an instruction manual, a contract, a poem, a diary, a coded message, or a satirical play. One can certainly give meaning to words independently of the context in which they were uttered or written, just as one can give meaning to spilled goat entrails or a random collection of

\footnotetext{
41 See EPSTEIN, supra note 1, at 54.

42 "A short string of characters may correspond to a word in more than one language; for instance, 'chair' means chair in English, while in French it means flesh." Sherri Irvin, Authors, Intentions and Literary Meaning, 1 PHILOSOPHY COMPASS 114, 114 (2006).
} 
star patterns, but then one is giving rather than ascertaining meaning. The very notion of ascertaining the meaning of a communication requires trying to understand what is being communicated and by whom, even if the communicator is oneself. ${ }^{43}$

The real question is: whose intentions determine communicative meaning in the context of the Constitution? Professor Epstein is right to reject reliance on the concrete, historical intentions of any particular set of drafters of the Constitution, but he is right for somewhat different reasons than he offers. Professor Epstein cites as the "great advantage" of reference to public meaning over private intentions that "the interpreter is far more likely to find a single standard meaning from reading the text than from attempting to reconcile the various separate understandings of draftsmen in the plural." ${ }^{44}$ This is not a reason that makes sense from the standpoint of an objective search for interpretative truth; a single discernible but wrong answer is not necessarily "better" in this respect than a cacophony of answers or no answer at all. It does, however, make some sense as a matter of adjudicative theory if one assumes that effective adjudication requires adjudicators to have a single discernible meaning to apply -- which is one more piece of evidence that Professor Epstein is at all points in his argument weaving an adjudicative rather than an interpretative theory, but let that pass. As I will explain later, this assumption that effective constitutional adjudication requires a single definitive constitutional meaning in every instance is false, but it is a widely shared, and even standard, assumption, and it is accordingly quite reasonable -- even if ultimately mistaken -- for Professor Epstein to make it. But even if it provided a good reason as a matter of adjudicative theory for choosing objective over subjective meaning as the ground for constitutional interpretation, it would not satisfy the

43 See Larry Alexander \& Saikrishna Prakash, “Is that English You're Speaking? ”: Why Intention Free Interpretation Is an Impossibility, 41 SAN DIEGO L. REV. 967 (2004).

44 EPSTEIN, supra note 1, at 46. 
requirements of determining meaning as a matter of first principle. The interpretative reasons for choosing objective over subjective meaning must relate to the superiority of one over the other as an accurate method for discerning communicative signals in a given context. Any other kind of argument is beside the point.

Guy Seidman and I have elsewhere sketched the interpretative case for making the locus of constitutional meaning the understandings that would have been held by a hypothetical reasonable person at the time of the Constitution's adoption. ${ }^{45}$ Importantly, we do not reach that conclusion by starting with the reader as the locus of meaning. Although that is how Professor Seidman and I initially presented the role of the reasonable person in constitutional interpretation, ${ }^{46}$ that was shorthand for an argument that we did not formally develop until 2006. Communicative meaning must be grounded in the intentions of the communicator, even if those intentions are necessarily shaped by the presumed expectations of readers, and even if those intentions are best understood -- as will often be the case, and perhaps even generally be the case where honest attempts at communication are involved ${ }^{47}-$ as the abstract intention to put out utterances that will then be given a public meaning by the reader. ${ }^{48}$ But at the most basic level, if

45 See Gary Lawson \& Guy Seidman, Originalism as a Legal Enterprise, 23 CONST. COMMENTARY 47 (2006). I plan to develop the case in much greater depth in a forthcoming work.

46 See Gary Lawson \& Guy Seidman, When Did the Constitution Become Law?, 77 NotRE DAME L. Rev. 1, 25 (2001).

47 Andrei Marmor correctly reminds us that legal statements are not always honest attempts at communication; they can be attempts at manipulation or evasion. See Andrei Marmor, Can the Law Imply More than It Says? On Some Pragmatic Aspects of Strategic Speech, in PHILOSOPHICAL FoundaTIONS OF LANGUAGE IN THE LAW, supra note 34, at 93-94. The Constitution presents itself as an honest attempt at communication, though to defend that proposition would require an extensive argument, which I will offer in a subsequent work.

48 See Scott Soames, Deferentialism: A Post-Originalist Theory of Legal Interpretation, 82 FordHAM L. REV. 597, 598 (2013). 
you are not trying to understand what someone is saying, you are not engaged in the enterprise of communication. $^{49}$

The key is to identify the author of the Constitution who is attempting to communicate. The Constitution itself provides the answer by declaring that its effective author - the entity whose intentions determine its communicative content -- is "We the People," ${ }^{, 50}$ which is a hypothetical construct rather than a concrete, intending person. The effective author of a legal document must be distinguished from the literal author. The literal author of the Constitution could plausibly be identified as the thirty nine signatories to the document, all of the people at the Constitutional Convention, all of the people at the various ratifying conventions, all of the people who chose to recognize the Constitution as authoritative, or any subset thereof (such as the Committee of Detail). But just as the effective author of a form power of attorney is the principal who propounds it rather than the anonymous employee of the publishing firm that literally typed the words, and the effective author of a will is the person whose estate is being distributed rather than the lawyer who actually crafted the plan, so the effective author of the Constitution is the entity that ordained and established it as a legal document. ${ }^{51}$ The Constitution itself identifies that entity as the hypothetical "We the People." 52

49 See RAYMOND W. GiBBS, JR., InTENTIONS IN THE EXPERIENCE OF MEANING 42 (1999) ("understanding the meaning of what another person says (or writes or creates) demands some recognition of that person's communicative intentions, even if we sometimes infer meanings different from that person's intended messages").

50 See U.S. CONST. Preamble.

51 Cf. GIBBS, supra note 49, at 220 ("I might even purchase a birthday card from a local store, present this to a friend, and claim authorship of the sentiments expressed in the card simply because I signed and sent the card to a particular person, even if as 'author' I am not historically connected to the person who wrote the text").

52 See Lawson \& Seidman, supra note 45, at 58-61. To be very clear: This is not a claim about actual political authority. We are not saying that "We the People" managed to create any kind of legal or political obligations on anyone. We are saying only that, for purposes of interpretation, the putative author of the Constitution is "We the People."

Couldn't one say instead that the Constitution's effective author is the state ratifying conventions, because their ratification gave the Constitution legal effect? See U.S. CONST. art. VII ("The Ratification of the Conventions of 
Moreover, when the literal author of a document is more than one person, the actual metaphysics of intentions require that the joint product be treated as though it was written by a single person or entity. Each joint author must, in other words, intend at some level that the work product be understood as the result of a hypothetical "author" who does not necessarily reflect the precise thoughts of any of the concrete individuals involved. ${ }^{53}$ Thus, Professor Epstein is right that a multiplicity of drafters requires looking beyond individual intentions - but he is right from the standpoint of interpretative theory rather than adjudicative theory.

Constructing the intentions of this hypothetical "We the People," understanding that term to represent a single hypothetical intending entity, roughly correlates with discerning the objective public meaning of the Constitution at the time of its adoption, given that "We the People" is both the author of and the (primary) intended audience for the act of communication represented by the document. ${ }^{54}$ To be sure, the hypothetical "We the People" is not the exclusive intended audience for the Constitution. The Supremacy Clause makes clear that at least part of the audience for the Constitution is real-world, concrete state court judges, who are specifically instructed to give the Constitution hierarchical priority in adjudication, ${ }^{55}$ and the Oath Clause makes clear that the audience also includes " $[\mathrm{t}]$ he Senators and Representatives before mentioned, and the Members of the several State Legislatures, and all executive and judicial

nine States, shall be sufficient for the Establishment of this Constitution between the States so ratifying the Same."). Nothing of substance would change about the proper interpretation of the Constitution if that were true (because the ratifying conventions are hypothetical entities in their own rights), but the answer is no. Article VII specifies the necessary and sufficient conditions for a certain legal and political event, but that event involves the establishment as governing law of "this" Constitution. In other words, the content of the document had already been determined (by virtue of its being ordained and established) before its Article VII "Establishment" as law took place. In 1788, the Constitution had the same meaning in Rhode Island and North Carolina as it had in New Hampshire and Connecticut, and it would have had the same meaning had it been defeated at five ratifying conventions.

53 See id. at 61-67.

54 See id. at $70-73$.

55 See U.S. Const. art. VI, § 2. 
Officers, both of the United States and of the several States." ${ }^{, 56}$ Moreover, the instrument might well be of interest to, for example, foreign courts that must in some circumstances apply American law, to foreign scholars doing comparative work, or perhaps to people seeking American citizenship who are not yet part of We the People. But the primary audience for We the People's communication is We the People. Accordingly, the best understanding of constitutional meaning must represent the intentions of We the People seeking to communicate with, among other entities, We the People. ${ }^{57}$ That is a good approximation of Professor Epstein's public meaning theory of constitutional interpretation.

Professor Epstein is also right that the bare text of the Constitution cannot be the whole story as to its meaning. ${ }^{58}$ Texts require contexts. The interpretation of any text requires background rules for interpretation that authors - real or hypothetical -- simply will not have the time, or possibly the inclination, to specify and that must be taken for granted. (And any explicit specifications would themselves have to be interpreted in light of some set of background principles.) Professor Epstein finds those background principles for interpreting the Constitution

56 Id. art. VI, § 3.

57 Saul Cornell objects to a focus on fictive readers as the locus of meaning as inconsistent with the thrust of modern literary theory. See Saul Cornell, Meaning and Understanding in the History of Constitutional Ideas: The Intellectual History Alternative to Originalism, 82 FORDHAM L. REV. 721,735 (2013). As is hopefully made clear in the text, in terms of literary theory, the closest analogue to the post-2006 Lawson/Seidman approach to constitutional interpretation would probably be the Nehamasian "postulated author," see Alexander Nehamas, The Postulated Author: Critical Monism as a Regulative Ideal, 8 CRITICAL INQUIRY 133, 145 (1981), rather than a fictive reader, though to the extent that "We the People" is the intended audience for, as well as the author of, the Constitution, any difference between a focus on authors and readers effectively vanishes in the context of constitutional interpretation. But analogies to disputes in literary theory are likely to be unhelpful in this context. The Constitution stipulates its author to be a hypothetical entity ("We the People"), even if that stipulation would not find favor with modern literary theorists. But see Irvin, supra note 41, at 123-25 (suggesting that postulated authorship has not entirely vanished from contemporary literary theory); William Nelles, A Hypothetical Implied Author, 45 STYLE 109 (2011) (same). And if Professor Seidman and I are right about the metaphysics of joint intentions, it again does not matter what literary theorists might think about hypothetical authors or fictive readers.

58 See EPSTEIN, supra note 1, at 573-75. 
in "the general [classical liberal] theory that animates the text," ${ }^{, 59}$ and thus concludes that the Constitution's "successful interpretation on all points dealing with text and its surrounding norms should be read in sync with the tradition of strong property rights, voluntary association, and limited government. ${ }^{, 60}$ This claim is part of a theory of interpretation rather than a theory of construction or adjudication to the extent that it purports to provide the context against which the communicative signals of the document must be understood.

There is no doubt that Professor Epstein at least partly has this interpretative focus in mind, and there is no doubt that he is at least partly right. There are specific clauses in the Constitution that rather plainly owe their provenance in large measure to classical liberalism (and I believe that at one time Professor Epstein claimed no more than this for classical liberal theory). It is difficult to understand the Take Care Clause ${ }^{61}$ without reference to the Glorious Revolution and its opposition to monarchical suspension of the laws. Article I and its list of enumerated powers reads very differently if one starts with the organic theory of the state rather than with the distinctively American eighteenth-century conception of limited government. Classical liberal political theory is part of the interpretative background of the Constitution in a way that, for example, Marxism simply is not. When the Fifth Amendment refers to "private property, ${ }^{, 62}$ the term includes the means of production and not simply small personal articles. But that is not enough to make the Constitution "The" classical liberal Constitution, in the sense that the entire document must be read, in all of its particulars, to conform to (be "in sync with") classical liberal theory. That would be true if and only if classical liberal political

59 Id. at $573-74$.

${ }^{60} I d$. at 53-54.

${ }^{61}$ U.S. ConST. art. II, § 2, cl. 3.

${ }^{62}$ Id. amend. V. 
theory was either the only relevant background principle of interpretation or had hierarchical priority over all other relevant background principles. And that is surely not the case. Indeed, at least one other background principle can claim interpretative priority over classical liberal theory in the event of a conflict.

How one interprets a document is a function of what kind of document it is. The background principles of interpretation are quite different for a poem than for a treatise on early English land law, even when both documents are written in the same language at the same point in time. One cannot interpret, in the sense of ascertaining the communicative signals contained in, the Constitution without knowing what kind of document one is interpreting.

Professor Epstein, as I understand him, agrees with this and, indeed, sees the Constitution as being one among a large class of legal instruments that share basic interpretative premises. Hence, he writes that " $[\mathrm{t}]$ he proper way to read a constitutional provision scarcely differs from the proper way to interpret other documents with legal effect: statutes, regulations, and contracts." 63

It is absolutely true that the Constitution's character as a legal document determines to a large extent the appropriate background rules of interpretation; it suggests, for example, that one should not be on the lookout for metaphors or onomatopoeia, as one might be when reading a poem or play, ${ }^{64}$ and that one should instead be on the lookout for technical words of art that have specialized meaning in the law. But the Constitution is not exactly like a statute, a regulation, or a contract (assuming, as I think is probably right, that those three entities have enough in common to be lumped together). It is a legal document, to be sure, but it belongs to a specific

\footnotetext{
63 Id. at 46.

64 See Richard A. Posner, LAw AND LiteratuUre: A Misunderstood RElation 213-14 (1988).
} 
class of legal documents that has - or, more pertinently, had in the late eighteenth century - its own distinctive principles of interpretation within the wider category of legal instruments.

Elsewhere, Rob Natelson (to whom is due virtually all of the credit for this crucial idea), Guy Seidman, and I develop at some length the proposition that the Constitution is, as James Iredell called it at the North Carolina ratifying convention, "a great power of attorney,"65 and thus must be understood in light of the principles of interpretation governing eighteenth-century fiduciary instruments. ${ }^{66}$ That is, the Constitution is not simply a legal document simpliciter, a superstatute, or a special kind of treaty or compact. The Constitution is fundamentally an agency instrument, in which the principal, "We the People," entrusts some measure of power over its affairs to a set of agents. This is not a claim about political theory suggesting that the Constitution actually worked, in some normatively binding fashion, an effective transfer of power. This is purely a descriptive claim about the kind of document that the Constitution is and accordingly about the appropriate background principles of interpretation that bear upon it.

Without repeating in full the lengthy argument for this characterization of the Constitution: The Constitution's text, structure, and history all suggest that Iredell was right, at least in broad-brush terms, about the appropriate characterization of the document. The Constitution most naturally reads like a grant of power from a principal (the "We the People" identified in the Preamble) to agents (federal officials and, to a very limited extent, state officials) to manage some portion of the principal's affairs - which is not at all surprising in a document primarily drafted by four agency lawyers (Oliver Ellsworth, Edmund Randolph, James

\footnotetext{
654 The Debate in the State CONVEntions On the Adoption of the Federal Constitution 148-49 (Jonathan Elliot, ed. 2d ed., 1907).

66 See Gary Lawson, Robert G. Natelson \& Guy I. Seidman, The Fiduciary Foundations of Federal Equal Protection, -- B.U.L. REV. - (2014) (forthcoming).
} 
Rutledge, and James Wilson) and a businessperson who routinely employed agents (Nathaniel Gorham). ${ }^{67}$ The Constitution is structured in much the same way as were other kinds of eighteenth-century fiduciary instruments. ${ }^{68}$ The founding generation widely understood the Constitution, and government in general, in fiduciary terms. ${ }^{69}$ Certain portions of the Constitution, such as the Necessary and Proper Clause, make sense only in light of eighteenthcentury fiduciary norms and understandings. ${ }^{70}$ Chief Justice Marshall's classic opinion in McCulloch v. Maryland ${ }^{71}$ took for granted the fiduciary character of the instrument. ${ }^{72}$ If the Constitution is not literally "a great power of attorney," it is something very close to it.

This is not the place to spin out the interpretative consequences of viewing the Constitution as a fiduciary instrument. That would require a book (which Mr. Natelson, Professor Seidman, and I are planning). For now, it is enough to point out that the background principles for interpretation that Professor Epstein and I both agree are necessary in order to understand the communicative signals conveyed by the constitutional text can be found most naturally in a source other than classical liberal political theory. The best place to look for principles for interpreting an agency instrument is the set of principles for interpreting agency

67 See Robert G. Natelson, The Framing and Adoption of the Necessary and Proper Clause, in GARY LAWSON,

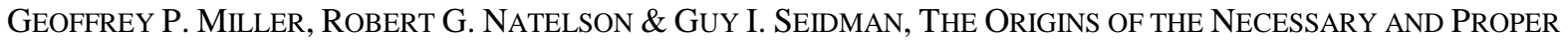
Clause 84, 85-86 (2010).

68 See Robert G. Natelson, The Original Meaning of the Constitution's "Executive Vesting Clause" - Evidence from Eighteenth-Century Drafting Practice, 31 WHITTIER L. REV. 1 (2009).

69 See Robert G. Natelson, The Constitution and the Public Trust, 52 BufF. L. Rev. 1077 (2004).

70 See Lawson, Miller, Natelson \& SeIdMAn, supra note 67, at 121-25.

7117 U.S. (4 Wheat.) 316 (1819).

72 See Gary Lawson \& David B. Kopel, Bad News for Professor Koppelman: The Incidental Unconstitutionality of the Individual Mandate, 121 YALE L.J. ONLINE 267 (2011). 
instruments. Eighteenth-century agency law as applied to the public realm is the first recourse for understanding the United States Constitution.

That does not mean that classical liberal political theory is irrelevant. As noted above, some constitutional clauses, such as the Take Care Clause, and terms, such as "private property," gain important aspects of their meaning from that background. It does mean, however, that running the entire Constitution through classical liberal theory to ensure that interpretations are "in sync with" the main thrust of classical liberalism is an interpretative mistake, though it may make considerable sense as a piece of constitutional construction. To be sure, it is quite likely that a straightforward application of what one might call "fiduciary originalism" will track in large measure the set of interpretative conclusions that one would reach through Professor Epstein's method, simply because eighteenth-century agency law concepts were in fact embedded in a classical liberal political culture. For instance, something like Professor Epstein's anti-circumvention principle is quite readily derivable from understanding the Constitution as an agency instrument. But the correspondence will not necessarily be perfect. The Dormant Commerce Clause, for example, leaps to mind as something that makes sense under classical liberal construction ${ }^{73}$ but not necessarily under fiduciary originalism. ${ }^{74}$

Professor Epstein asks all of the right interpretative questions, and he answers those questions from within a fundamentally sound framework concerning the nature of interpretation. He just picked the wrong set of background principles for interpreting the Constitution. Or so I think.

\footnotetext{
73 See EPSTEIN, supra note 1, at 227-44.

74 See Tyler Pipe Industries, Inc. v. Washington State Dep’t of Revenue, 483 U.S. 232, 259-65 (Scalia, J., concurring in part and dissenting in part).
} 
At least some parts of Professor Epstein's project - his theory of precedent, for example cannot be understood as a theory of interpretation rather than as a theory of adjudication. As an interpretative matter, I have elsewhere, and somewhat notoriously, expressed the view that the Constitution forbids the use of precedent to determine its meaning beyond treating precedent as a source of information about original meaning, ${ }^{75}$ and I will not revisit that debate here. Instead, I want to explore the extent to which the Constitution purports to prescribe rules for adjudication apart from the use of precedent and the extent to which those interpretatively-derived rules are consistent with Professor Epstein's classical liberal constitutionalism.

I want to be very clear about the scope and nature of this argument. I am not arguing, as a normative matter, for any particular approach to constitutional adjudication. Any such claim would have to be justified by reference to moral theory, and I do not hold myself out as a moral theorist. Rather, my claim is that if one interprets the Constitution - i.e., discerns the communicative signals that it contains - one finds instructions, albeit implicit ones, about how to conduct adjudication under the Constitution. Thus, in the form of a hypothetical imperative: If one believes that adjudication should be conducted in accordance with the meaning of the Constitution, that meaning includes very powerful instructions about how to conduct adjudications.

One set of adjudicatory instructions is quite explicit: The Supremacy Clause tells state courts that they must decide cases by giving hierarchical preference to certain specified federal

75 See Gary Lawson, The Constitutional Case Against Precedent, 17 HARV. J. L. \& PUB. POL'Y 23 (1994); Gary Lawson, Mostly Unconstitutional: The Case Against Precedent Revisited, 5 Ave MARIA L. J. 1 (2007). 
laws, including the law of the Constitution, in the event of a conflict between those federal norms and any other source of law:

This Constitution, and the Laws of the United States which shall be made in Pursuance thereof; and all Treaties made, or which shall be made, under the Authority of the United States, shall be the supreme Law of the Land; and the Judges in every State shall be bound thereby, any Thing in the Constitution or Laws of any state to the Contrary notwithstanding. ${ }^{76}$

By its terms, this provision only gives instructions to state courts, and it only tells them to favor certain federal laws over competing state statutes or constitutions. It does not purport to command federal officials or state officials other than state judges, and it does not specify that the Constitution is superior to federal statutes or treaties. But it is not difficult to glean from the structure and context of the Constitution as a whole an implicit, broader adjudicative principle that applies to all actors - state or federal, judicial or legislative or executive - and that places the Constitution hierarchically above all other claimed sources of law, including federal statutes and treaties. This is the structural argument for constitutional supremacy that John Marshall made in Marbury v. Madison, ${ }^{77}$ and it is interpretatively correct. ${ }^{78}$ This much I suspect is uncontroversial - at least in its conclusions if not in its reasoning.

But if that is the only set of adjudicative instructions contained in the Constitution, then there would seem to be a fairly large space for constitutional construction. Suppose one accepts that the Constitution prescribes its own priority in adjudication. That still leaves the problem of

\footnotetext{
76 U.S. CONST. art. VI, cl. 2.

775 U.S. (1 Cranch) 137 (1803).

78 See Gary Lawson, Rebel without a Clause: The Irrelevance of Article VI to Constitutional Supremacy, 110 MiCH. L. REV. FIRST IMPRESSIONS 33 (2011).
} 
determining the meaning of the Constitution that needs to be applied in adjudication. Grant for the moment that fiduciary originalism is the appropriate methodology for determining constitutional meaning. What happens when fiduciary originalism cannot prescribe a uniquely correct interpretative answer to a particular question?

One need not spell out a detailed theory of fiduciary originalism to realize that it cannot possibly claim to prescribe a uniquely correct interpretative answer to every question that arises. No theory that involves anything more complicated than tossing a coin or having the parties armwrestle for the victory could plausibly claim such a thing. Even if the standard of proof for constitutional claims is something as low as "better than available alternatives,"79 there will surely be some set of real-world disputes in which there simply is no good interpretative reason to prefer one view over another, ${ }^{80}$ and the set of such disputes grows as the appropriate standard of proof rises. As Professor Epstein puts it, in at least some cases, such as the precise application of principles of due process, "even the strongest commitment to an originalist method of interpretation requires judges [or other interpreters] to engage in subsequent elaboration ... given the inability to specify any unique set of procedures for all different cases." ${ }^{\prime 1}$

This zone of interpretative uncertainty is generally taken as the sphere for constitutional construction. ${ }^{82}$ After all, so the argument goes, adjudicators have to decide cases; they cannot simply throw up their hands and say, "beats us what the Constitution means." If the correct

\footnotetext{
79 On the crucial role of standards of proof in interpretation, see Gary Lawson, Proving the Law, 86 Nw. U.L. REV. 859 (1992).

80 See BALKIN, supra note 32, at 22 (suggesting that originalism as a method for ascertaining meaning "will not be sufficient to decide a wide range of controversies"); Barnett, supra note 34, at 419-20 (noting that the original meaning of a text can "run out").

81 EPSTEIN, supra note 1, at 47.

82 See Gary Lawson, Dead Document Walking, 92 B.U.L. REV. 1225, 1232-33 (2012).
} 
method of interpretation -- in my case fiduciary originalism, but for this purpose the precise theory does not matter -- cannot provide a uniquely correct answer to interpretative questions, then something else must fill the gap in adjudication, and that something else must be constitutional construction. As Professor Epstein explains, "[i]t is idle to argue that this task [of determining the implicit qualifications of constitutional texts] can be avoided because of the latent indeterminacy." 83

With all due respect (and where Professor Epstein is concerned, the respect due is almost incalculable): no, it actually isn't idle at all. Quite to the contrary, interpretative indeterminacy fully justifies adjudicators throwing up their hands and saying, "beats us what the Constitution means." Such a declaration does not prevent them from deciding cases, and it does not prevent them from deciding cases in accordance with the Constitution.

I have laid out this argument elsewhere more than once, ${ }^{84}$ but in brief: When fact-finders are called upon to resolve disputes, they do not actually have to reach a definitive conclusion about the facts in order to decide the case. They do not have to settle on a single account of what happened. Rather, they simply need to find that whichever party bears the burden of proof on a matter has failed to establish its version of the facts with whatever degree of certainty is required by the applicable standard of proof. It is perfectly sensible for the fact-finder to throw up its hands and say, "We have no idea what actually happened, and therefore party X, who bore the burden of proof on this matter, loses." A legal system that contains allocations of burdens of proof, along with accompanying standards of proof that define those burdens, can be entirely determinate as a matter of adjudication even if it is partly, or even largely, indeterminate as a

83 EPSTEIN, supra note 1 , at 47.

84 See Lawson, supra note 81, at 1233-35; Gary Lawson, Legal Indeterminacy: Its Cause and Cure, 19 HARV. J. L. \& PUB. POL'Y 411, 421-28 (1996). 
matter of factual ascertainment. Successful, determinate adjudication does not require factual determinacy.

While the American legal system generally (with a few notable exceptions, such as the Chevron ${ }^{85}$ doctrine and the "clearly established law" doctrine in official immunity cases ${ }^{86}$ and habeas corpus review ${ }^{87}$ ) does not use the language of burdens of proof and standards of proof to describe what happens when legal rather than factual matters are at stake, there is no reason why it could not do so. It is perfectly sensible for a system of adjudication to say that a case can be resolved against a party, even without a judicial determination of the applicable law, simply because the party with the burden of proof has failed to demonstrate, in accordance with the appropriate standard of proof, that the law has a meaning that entitles that party to a judgment. Successful adjudication does not require law-finders to specify the precise content of the law any more than it requires fact-finders to specify a precise account of the facts. It simply requires an allocation of the burden of proof and specification of a standard of proof. Adjudication can handle legal indeterminacy just as readily as it can handle factual indeterminacy.

Fine and well, one might say - this is all theoretically possible. But what does that have to do with the actual Constitution?

Suppose that the Constitution contained an Article VIII that said:

\footnotetext{
85 The Chevron doctrine is named for Chevron U.S.A.v. National Resources Defense Council, Inc., 467 U.S. 837 (1984), but that is a misnomer, as the doctrine actually has almost nothing to do with the case. For the real story of the development of the Chevron doctrine, see Gary Lawson \& Stephen Kam, Making Law Out of Nothing At All: The Origins of the Chevron Doctrine, 65 ADMIN. L. REV. 1 (2013).

86 See Harlow v. Fitzgerald, 457 U.S. 800 (1982). For a brief summary of current law (if one may use the term loosely) on the subject, see John C. Jeffries, Jr., The Liability Rule for Constitutional Torts, 99 VA. L. REV. 207, 251-57 (2013).

87 See 28 U.S.C. 2254(d)(1) (2012).
} 
In deciding cases under this Constitution, apply the following set of adjudicative principles. When federal actions are challenged, the initial burden of proof is placed on whichever party is relying on that federal action for its case to show that the action is within the enumerated power of the relevant federal institution(s). If that burden of proof is not met, the party whose case depends on that exercise of federal power loses. If the federal action prima facie falls within an enumerated power but is claimed to be invalid because of an affirmative limitation on federal power external to the enumeration, the party asserting that affirmative limitation bears the burden of proof and accordingly loses if that burden is not met and the claim of invalidity is essential to its case. And where state actions are challenged as inconsistent with the federal Constitution, the party challenging the state action bears the burden of proof (unless the claim pertains to a federally enumerated power of a state concerning federal elections or constitutional amendments) and bears as well the corresponding risk of loss in the event that the burden is not satisfied. In all instances, the standard of proof for establishing a relevant legal claim under this Constitution shall be ---.

This provision would specify a set of adjudicative principles that would not require law-finders actually to ascertain the meaning of the Constitution in order to decide cases. They would simply need to determine if the party relying on a particular claimed constitutional meaning had demonstrated that meaning to be correct in accordance with the appropriate standard of proof. A judgment against that party would not "fix" the meaning of the Constitution in any relevant sense; it would simply stand as an assessment of the quality of the proof offered by one particular party. There would be no need for constitutional construction to fill in the meaning of 
constitutional provisions, because it would not be essential to adjudication that the law-finder settle on any particular meaning.

But, of course, the Constitution contains no such Article VIII. Or does it?

The allocation of burdens of proof described in this hypothetical Article VIII is, I think, implicit in the actual Constitution. The principle that "he who asserts must prove" is a basic principle of rational thinking. It therefore serves as a background principle for understanding the federal Constitution just as surely as do the laws of logic and basic rules of English grammar. And the fundamental constitutional principle of enumerated federal powers and (with the possible exception of some matters regarding federal elections and constitutional amendments) unenumerated state powers establishes the allocations of burdens of proof described in my Article VIII. Anyone claiming the benefit of an exercise of federal power must be asserting in the first instance that such power is authorized by the Constitution; otherwise, that exercise of power has no legal status. The initial burden of proof is thus on whoever is relying on a valid exercise of federal power, though that burden shifts if the relevant constitutional assertion involves a claim of an affirmative limitation on a concededly enumerated power. In the case of challenges to state authority under the federal Constitution, precisely the opposite burden of proof applies. The person relying on state authority need not, as a federal constitutional matter, show some affirmative authorization for the state to act (except in a few special cases). The person challenging state authority as inconsistent with some affirmative federal prohibition is the relevant constitutional asserter and thus bears the burden of proof. This scheme does not neatly comport with classical liberal theory, because it sharply distinguishes - as liberal theory would not - between exercises of governmental power by federal and state actors. In essence, it creates a presumption against the validity of federal power and in favor of state power. Neither 
Professor Epstein nor I find it normatively attractive to give exercises of state power a presumption of validity, but that is the result that the Constitution prescribes. ${ }^{88}$

A scheme for constitutional adjudication without need for definitive determinations of constitutional meaning is thus implicit in the structure of the Constitution. ${ }^{89}$

Well, not quite. In order to make this adjudicative scheme work, one needs to know the standard of proof for claims about constitutional meaning. It is not enough to know who has the burden of proof; one also needs to know what that person has to do in order to satisfy the burden. Does the constitutional structure implicitly provide a standard of proof?

I don't see one. That does not mean that it is not there, but I do not see it. If no such standard of proof is implicit in the constitutional structure, then there is at least one respect in which constitutional construction is necessary for successful adjudication: One must select - and that means select rather than ascertain - the standard of proof for claims about constitutional meaning. Indeed, there is no obvious reason why there must be a single standard of proof for all kinds of constitutional claims - no more than there is a single standard of proof for all factual claims. ${ }^{90}$

Does classical liberalism have anything to say about the appropriate standard of proof? Perhaps it does. Classical liberalism starts with a deep suspicion of governmental action, whether state or federal, and one could conceivably derive from this starting point a set of

88 Accordingly, it is not appropriate to describe this particular allocation of burdens of proof as "Thayerian." See James Bradley Thayer, The Origin and Scope of the American Doctrine of Constitutional Law, 7 HARV. L. REV. 129 (1893). Indeed, it is anti-Thayerian. Thayer applied a clear-statement rule to acts of Congress but not to state action. See id. at 144. The Constitution's rule is precisely the reverse.

89 Larry Solum has offered a lengthy rebuttal to this claim, see Solum, supra note 30, at 512-23, and it would take an equally long discussion here to respond in kind. That must await another day, but no one should make up his or her mind about the possibility of replacing construction with default rules without first reading Professor Solum's careful analysis (not to mention the next paragraph of this Comment).

90 Thus, Professor Solum may be right about the unavoidability of some kind of construction zone, albeit for different reasons than he offers. 
standards of proof that favors the claims of liberty in all cases, along the lines of Randy Barnett's "presumption of liberty."91 Indeed, it is quite possible that Professor Epstein's entire set of conclusions about constitutional adjudication could be reached through judicious use of standards of proof for various claims. If constitutional construction is inevitable, Professor Epstein's construction might be able to make a very strong case for primacy among serious contenders in the modern world. That, however, is a matter for moral theorists about which this humble law professor has no useful comment.

91 RANDy E. BARnett, Restoring the Lost CONSTITUtion: THE PRESUMPTION OF LiBERTy (2004). 